\title{
PENGARUH ADVERSITY QUOTIENT TERHADAP KEMAMPUAN PEMECAHAN MASALAH MATEMATIS SISWA SD
}

\author{
Andi Nurlaelah ${ }^{1}$, Muhammad Ilyas ${ }^{2}$, Nurdin ${ }^{3}$ \\ Universitas Cokroaminoto Palopo ${ }^{1,2,3}$ \\ Email: andinurlaelah70@gmail.com ${ }^{1}$, muhammadilyas949@yahoo.com², \\ enambelasnurdin@gmail.com ${ }^{3}$
}

\begin{abstract}
Abstrak. Kemampuan Pemecahan masalah adalah suatu kemampuan yang baik untuk dikembangkan khususnya dalam mata pelajaran matematika. Mengembangkan kemampuan pemecahan masalah membutuhkan metode dan cara yang tepat khususnya siswa sekolah dasar. Adversity Quotient merupakan suatu pertimbangan internal dari dalam diri siswa yang diindikasikan dapat mempengaruhi kemampuan pemecahan masalah siswa. Penelitian ini bertujuan untuk (1) melihat gambaran Adversity Quotient dan Kemampuan Pemecahan Masalah Matematis Siswa SD, (2) untuk mengetahui pengaruh Adversity Quotient terhadap kemampuan pemecahan masalah matematis siswa SD. Populasi pada penelitian ini adalah seluruh Siswa Sekolah Dasar kelas V dan VI di Kecamatan Malili. Sampel pada penelitian ini adalah 153 siswa dengan cara Purposive Sampling. Data Adversity Quotient diperoleh menggunakan angket dan Kemampuan Pemecahan Masalah menggunakan tes. Hasil penelitian ini adalah (1) Adversity Quotient berada pada kategori sedang atau camper (2) Kemampuan Pemecahan Masalah Matematis Siswa SD berada pada kategori sedang. (3) Terdapat pengaruh Adversity Quotient terhadap Kemampuan Pemecahan Masalah Matematis.
\end{abstract}

\section{Kata Kunci: Adversity Quotient, Kemampuan Pemecahan Masalah Matematis}

\begin{abstract}
Problem solving ability is a good ability to be developed, especially in mathematics. Developing problem solving skills requires appropriate methods and methods, especially for elementary school students. Adversity Quotient is an internal consideration from within students which is indicated to affect students' problem solving abilities. This study aims to (1) see the description of Adversity Quotient and Mathematical Problem Solving Ability of Elementary School Students, (2) to determine the effect of Adversity Quotient on elementary students' mathematical problem solving ability. The population in this study were all elementary school students in grades V and VI in Malili District. The sample in this study was 153 students by means of purposive sampling. Adversity Quotient data obtained using a questionnaire and Problem Solving Ability using a test. The results of this study are (1) Adversity Quotient is in the medium category or camper (2) Mathematical Problem Solving Ability Elementary school students are in the medium category. (3) There is an effect of Adversity Quotient on Mathematical Problem Solving Ability.
\end{abstract}

\section{Keywords: $\quad$ Adversity Quotient, Mathematical Problem Solving Abvility}

\section{A. Pendahuluan}

Salah satu kemampuan berpikir yang dapat dikembangkan dalam matematika adalah kemampuan pemecahan masalah. Pemecahan masalah matematis telah lama dipandang sebagai aspek penting dari matematika, pengajaran matematika, dan pembelajaran matematika (Liljedahl, Santos-Trigo, Malaspina, \& Bruder, 2016). Pemecahan masalah matematis adalah suatu kemampuan siswa untuk menyelsaikan soal matematika dimana prosesnya tidak langsung ditemukan oleh siswa. Jika suatu masalah diberikan kepada seorang siswa yang dapat langsung diselesaikan dengan benar, maka soal tersebut bukanlah suatu masalah matematis bagi siswa (Widjajanti, 2009).

Kemampuan pemecahan masalah saat ini telah mejadi fokus pada pembelajaran matematika disemua jenjang Pendidikan mulai dari SD sampai pada Pendidikan tinggi. Pemecahan masalah matematis dibutuhkan oleh setiap siswa terkhusus untuk dalam 
meningkatkan daya pikirnya. Siswa yang memiliki daya pikir yang baik cenderung mampu berpikir kritis, kreatif, dan bernalar.

Setiap siswa tidak dapat menghindari dari kesulitan dalam belajar matematika. Perlu disadari oleh siswa bahwa pada umumnya siswa mengalami kesulitan dalam belajar matematika dengan tingkat kesulitannya yang berbeda-beda. Ada siswa yang merasa kesulitan pada pokok bahasan tertentu, ada juga siswa yang merasakan kesulitan pada bidang matematika tertentu, dan ada juga merasa kesulitan untuk seluruh materi matematika. Sehingga dapat dipastikan setiap siswa yang belajar matematika pernah mengalami kesulitan (Sudarman, 2012).

Terdapat beberapa faktor yang mempengaruhi kemampuan pemecahan masalah matematis, diantaranya, Adversity Quotient (AQ). AQ merupakan kemampuan siswa untuk menghadapi masalah. Menurut Hikmatussyarifah, Hasanah, \& Tarma, 2016) AQ merupakan bentuk kecerdasan yang melatar belakangi kesuksesan seseorang dalam menghadapi sebuah tantangan disaat terjadi kesulitan atau kegagalan.

Adversity Quotient (AQ) atau ketahanmalangan merupakan kemampuan seseorang untuk menguasai tantangan yang ada dan mengubah tantangan-tantangan tersebut menjadi peluang (Dewi, 2017). Hal tersebut senada dengan pendapat Rosita \& Rochmad (2016) Kemampuan yang ada pada diri seseorang dalam menghadapi suatu tantangan atau masalah dan mencari penyelesaian dari masalah tersebut dikenal dengan AQ. Adversity Quotient juga merupakan kemampuan individu untuk menggerakan tujuan hidup kedepan, dan juga sebagai pengukuran tentang bagaimana seseorang berespon terhadap kesulitan (Dewi \& Suhendri, 2016). Terdapat beberapa istilah lain yang menggambarkan Adversity Quotient yang dikemukakan oleh beberapa ahli dalam (Sudarman, 2012) yaitu kecerdasan ketahan malangan, Adversity Quotient adalah potensi kegigihan, Adversity Quotient adalah kehandalan mental, dan Adversity Quotient adalah kecerdasan ketangguhan. Adversity Quotient merupakan suatu indikator yang dapat digunakan untuk mengukur kesuksesan seseorang. Adversity Quotient dapat diartikan sebagai kemampuan individu dalam mengatasi kesulitan atau masalah dengan cara cerdas. Artinya adalah, sesorang yang memiliki Adversity Quotient yang baik tidak akan mudah menyerah, stress, atau putus asa dalam menghadapi masalah.

Stoltz (2000) menyatakan bahwa bukan hanya IQ maupun EQ tetapi Adversity Quotient juga memiliki pengaruh yang besar dalam menentukan keberhasilan siswa dalam belajar. Adversity Quotient dapat memberi dampak pada hasil belajar matematika siswa, karena dalam belajar matematika siswa memungkinkan dihadapkan dengan masalah matematika yang erat hubungannya dengan kehidupan sehari-hari. Siswa dengan Adversity Quotient tinggi akan memiliki motivasi yang tinggi pula untuk menyelesaikan masalah matematika. Mereka menganggap bahwa masalah matematika merupakan tantangan bagi mereka yang patut untuk diselesaikan. Dengan demikian, siswa dengan Adversity Quotient tinggi cenderung berbanding lurus dengan kemampuan pemecahan masalah matematis yang tinggi pula.

Sejalan dengan pendapat Stolz, (Rosita \& Rochmad, 2016) mengemukakan bahwa Adversity Quotient merupakan kemampuan yang ada pada diri seseorang dalam menghadapi suatu tantangan atau masalah dan mencari penyelesaian dari masalah tersebut. Seseorang dapat menyelesaikan atau memecahkan masalah yang ada dengan baik apabila didukung oleh kemampuan menyelesaikan masalah yang baik pula.

Adversity Quotient dikategorikan menjadi tiga tingkatan yaitu quitter (Rendah), camper (sedang), dan climber (tinggi). Siswa quitter adalah siswa yang menjauhi permasalahan. Ciriciri anak siswa quitter, misalnya: usahanya yang dikerahkan sangat kurang, begitu mendapatkan kesulitan maka siswa tersebut akan menyerah, dan tidak berani menghadapi permasalahan. Siswa quitter adalah mereka yang menggap bahwa matematika adalah pembelajaran atau matei yang sulit, berteletele, membingunkan, dan memusingkan. Motivasi yang dimiiliki siswa quitter sangat kurang, sehingga ketika menghadapi kesulitan yang kecil dalam menyelesaikan soal matematika mereka langsung menyerah dan berhenti tanpa adanya usaha sedikitpun. 
Siswa camper adalah siswa yang tak mau mengambil risiko yang terlalu besar dan merasa puas dengan kondisi atau keadaan yang telah di capainya saat ini. Siswa cenderung mengabaikan kemungkinan yang bakal diperoleh. Siswa camper cepat puas atau selalu merasa cukup berada di posisi tengah. Mereka tidak memaksimalkan usahanya walaupun peluang dan kesempatannya ada. Tidak ada usaha untuk lebih giat belajar. Dalam belajar matematika siswa camper tidak berusaha semaksimal mungkin. Mereka berusaha sekedarnya saja. Mereka berpandangan bahwa tidak perlu nilai tinggi yang penting lulus, tidak perlu juara yang penting naik kelas.

Siswa climber adalah anak yang mempunyai tujuan atau target. Untuk mencapai target itu, ia mampu mengusahakan dengan ulet dan gigih. Tak hanya itu, ia juga memiliki keberanian dan disiplin yang tinggi. Ibarat orang bertekad mendaki gunung sampai puncak, ia akan terus mencoba sampai yakin berada di puncak gunung. Siswa climber memiliki motivasi yang tinggi (Sudarman, 2012).

AQ tentunya sangat berperan dalam matematika, pada umumnya, siswa yang memiliki AQ tinggi senang akan tantangan sebagimana yang ada pada pelajaran matematika (Sudarman, 2012). Masalah matematika yang dihadapi siswa AQ tinggi akan direspon positif dan optimis sehingga siswa memiliki motivasi yang tinggi untuk menyelesaikannya. Sehingga siswa yang AQ tinggi biasanya berperan sebagai problem solver. Sebaliknya, siswa yang memiliki AQ rendah tentunya akan mengalami kesulitan untuk memecahkan masalah matematis tersebut dan akan merasa stres serta tidak nyaman. Perasaan yang tidak nyaman ini tentunya menurunkan motivasi siswa dalam belajar matematika, sehingga performanya kurang baik.

Berdasarkan hasil penelitian dari (Hidayat \& Sariningsih, 2018) Siswa AQ quitters dalam memecahkan masalah mampu memahami masalah dengan menuliskan apa yang diketahui dan apa yang ditanyakan dan menjelaskan masalah dengan kalimat sendiri sedangkan Siswa AQ campers dalam memecahkan masalah mampu melaksanakan tiga tahapan Polya yaitu memahami masalah, merencanakan pemecahan, dan melaksanakan rencana dan Siswa AQ climbers dalam memecahkan masalah mampu melaksanakan keempat tahap Polya yaitu mampu memahami masalah, merencanakan pemecahan masalah, menyelesaikan masalah melalui strategi pemecahan masalah, serta memeriksa kembali hasil dan proses dan menyimpulkan hasil penyelesaian

Berdasarkan pemaparan di atas maka penelitian ini bertujuan untuk mengetahui gambaran Adversity Quotient Siswa SD, untuk mengetahui gambaran Kemampuan Pemecahan Masalah Matematis Siswa, dan untuk mengetahui pengaruh Adversity Quotient terhadap kemampuan pemecahan masalah matematis siswa SD.

\section{B. Metode Penelitian}

Jenis Penelitian ini adalah Penelitian Ex-Post Facto yang bertujuan untuk mengetahui pengaruh Adversity Quotient dan Self Determination terhadap Kemampuan Pemecahan Masalah Matematis.

Penelitian ini dilaksanakan di Kecamatan Malili Kabupaten Luwu Timur. Subjek penelitian ini adalah siswa Sekolah Dasar yang ada di Kecamatan Malili. Penelitian ini akan dilaksanakan pada bulan Mei - Juni tahun 2021. Pada penelitian ini yang menjadi populasi adalah seluruh Siswa Sekolah Dasar yang terdapat di Kecamatan Malili, Kabupaten Luwu Timur, Porvinsi Sulawesi Selatan. Kecamatan Malili, Kabupaten Luwu timur memiliki 23 Sekolah pada jenjang Sekolah Dasar. Pada penelitian ini sampel yang dipilih sebanyak 153 orang dengan menggunakan Purposive sampling.

Pada penelitian ini dilakukan dua Teknik pengumpulan data yakni Teknik Tes dan Teknik Non Tes. Teknik Tes dan non tes. Tes adalah suatu alat ukur atau prosedur terencana yang digunakan untuk mengukur kemampuan dan pengetahuan peserta didik. Tes pada penelitian ini digunakan untuk mengukur kemampuan pemecahan masalah matematis siswa sekolah dasar. 
Non tes adalah suatu alat atau suatu teknik penilaian peserta didik yang dilakukan tanpa menguji peserta didik tetapi dengan melakukan pengamatan secara sistematis. Teknik non tes yang digunakan pada penelitian ini adalah Teknik Penyebaran angket. Angket ini yaitu Angket Adversity Quotient.

Kegiatan analisis data terbagi menjadi dua yakni kegiatan mendeskripsikan data dan melakukan uji statistik (inferensi). Kegiatan mendeskripsikan data adalah menggambarkan data yang ada guna memperoleh bentuk nyata dari responden, sehingga lebih mudah dimengerti peneliti atau orang lain yang tertarik dengan hasil penelitian yang dilakukan. Kegiatan mendeskripsikan data dapat dilakukan dengan pengukuran statistik deskriptif

Adapun tingkat Adversity Quotient siswa dikelompokkan berdasarkan tiga tipe atau tingkatan Adversity Quotient yaitu climber (tinggi), champer (sedang) dan quitter (rendah)

Table 1 Kategeri Adversity Quotient

\begin{tabular}{lc}
\hline \multicolumn{1}{c}{ Kategori } & Rentang \\
\hline Tinggi (Climber) & $X \geq \mu+\sigma$ \\
Sedang (Camper) & $\mu-\sigma \geq X \geq \mu+\sigma$ \\
Rendah (Qutter) & $\mu-\sigma \geq X$ \\
\hline
\end{tabular}

Stolz (Jana \& Nugrahayuningtyas, 2019).

Dimana:

$\boldsymbol{X} \quad$ : Skor AQ setiap Individu

$\boldsymbol{\mu} \quad$ : Rata-rata Skor AQ

$\boldsymbol{\sigma} \quad$ : Deviasi Standar Skor AQ

Teknik analisis data inferensial yang digunakan dalam penelitian ini adalah regresi linier sederhana.

\section{Hasil Penelitian dan Pembahasan \\ 1. Hasil Penelitian}

Data tentang Adversity Quotient siswa SD di Kecamatan Malili diperoleh dengan menggunakan angket skala 4 yang disebar dengan menggunaka formular online. Hasil pengumpulan data adversity quotient selanjutnya di tabulasi dan dicari nilai rata-rata, Median, variansi, standar deviasi, nilai minimum, nilai maksimum, dan rentang skornya. Data Adversity Quotient selanjutnya di kategorikan berdasarkan kategori tinggi, sedang, dan rendah dengan menggunakan hubungan antara rata-rata dan standar deviasi. Adapun gambaran Adversity Quotient siswa SD di Kecamatan Malili disajikan pada tabel di bawah ini.

\section{Table 2 Statistika Deskriptif Adversity Quotient}

\begin{tabular}{lr}
\hline Statistik & Nilai \\
\hline Rata-Rata & 87.92 \\
Median & 87 \\
Variansi & 124.72 \\
Standar Deviasi & 11.17 \\
Minimum & 60 \\
Maximum & 120 \\
Rentang & 60 \\
\hline
\end{tabular}

Berdasarkan data di atas maka dapat dijelaskan bahwa Rata-rata skor Adversity Quotient adalah 87.92 dengan sebesar Median 87 dan Variansi sebesar 124.72 serta Standar Deviasi 11.17. Data pada tabel di atas juga menjelaskan bahwa skor minimum Adversity Quotient siswa di Kecamatan Malili adalah 60 dan nilai maksimum sebesar 120 sehingga rentang skornya 60. 
Data pada tabel di bawah ini memperlihatkan kategori Adversity Quotient siswa di Kecamatan Malili.

Table 3 Kategori Adversity Quotient

\begin{tabular}{lc}
\hline Kategori Adversity Quotient & Jumlah Siswa \\
\hline Rendah & 13 \\
Sedang & 122 \\
Tinggi & 18 \\
\hline
\end{tabular}

Data di atas memperlihatkan bahwa jumlah siswa dengan Adversity Quotient Rendah sebanyak 13 siswa, kategori sedang sebanyak 122 siswa, dan kategori tinggi sebanyak 18 siswa.

Data tentang Kemampuan Pemecahan Masalah Matematis siswa SD di Kecamatan Malili diperoleh dengan menggunakan tes yang disebar dengan menggunakan formulir online. Jawaban siswa dikumpulkan dengan menggunakan fitur upload file pada formular tersebut. Hasil pengumpulan data Kemampuan Pemecahan Masalah Matematis selanjutnya di tabulasi dan dicari nilai rata-rata, Median, variansi, standar deviasi, nilai minimum, nilai maksimum, dan rentang skornya. Data Kemampuan Pemecahan Masalah Matematis selanjutnya di kategorikan berdasarkan kategori tinggi, sedang, dan rendah dengan menggunakan hubungan antara rata-rata dan standar deviasi. Adapun gambaran Kemampuan Pemecahan Masalah Matematis siswa SD di Kecamatan Malili disajikan pada tabel di bawah ini.

Table 4 Statistika Deskriptif Kemampuan Pemecahan Masalah Matematis

\begin{tabular}{lr}
\hline Statistik & Nilai \\
\hline Rata-Rata & 66,76 \\
Median & 66 \\
Variansi & 163,079 \\
Standar Deviasi & 12,77 \\
Minimum & 40 \\
Maximum & 100 \\
Rentang & 60 \\
\hline
\end{tabular}

Berdasarkan data di atas maka dapat dijelaskan bahwa Rata-rata skor Kemampuan Pemecahan Masalah Matematis adalah 66,76 dengan Median sebesar 66 dan Variansi sebesar 163.08 serta Standar Deviasi 12.77. Data pada tabel di atas juga menjelaskan bahwa skor minimum Kemampuan Pemecahan Masalah Matematis siswa di Kecamatan Malili adalah 40 dan nilai maksimum sebesar 100 sehingga rentang skornya 60.

Data pada tabel di bawah ini memperlihatkan kategori Kemampuan Pemecahan Masalah Matematis siswa di Kecamatan Malili.

Table 5 Kategori Kemampuan Pemecahan Masalah Matematis

\begin{tabular}{lc}
\hline Kategori Kemampuan Pemecahan Masalah Matematis & Jumlah Siswa \\
\hline Rendah & 17 \\
Sedang & 118 \\
Tinggi & 18 \\
\hline
\end{tabular}

Data di atas memperlihatkan bahwa jumlah siswa dengan Kemampuan Pemecahan Masalah Matematis Rendah sebanyak 17 siswa, kategori sedang sebanyak 118 siswa, dan kategori tinggi sebanyak 18 siswa.

untuk mengetahui pengaruh Adversity Quotient $\left(X_{1}\right)$ dengan Kemampuan Pemecahan Masalah Matematis (Y) dilakukan dengan menggunakan uji regresi linier sederhana. Adapun hasil uji regresi linier sederhana disajikan pada tabel di bawah ini. 
Table 6 Output Model of Summary Hipotesis 1

\begin{tabular}{ccccc}
\hline Model & $\mathrm{R}$ & $\mathrm{R}$ Square & Adjusted R Square & $\begin{array}{c}\text { Std. Error of the } \\
\text { Estimate }\end{array}$ \\
\hline 1 & $.748 \mathrm{a}$ & .560 & .557 & 8.497 \\
\hline
\end{tabular}

Berdasarkan tabel model of summary diatas diperoleh bawha nilai Nilai R Square atau koefisien Determinasi adalah $0,560 \times 100 \%=56,0 \%$. Sehingga dapat nyatakan bahwa variabel bebas Adversity Quotient $\left(X_{1}\right)$ memiliki pengaruh kontribusi sebesar $56.0 \%$ terhadap Kemampuan Pemecahan Masalah Matematis $(Y)$.

Table 7 Uji ANOVA Hipotesis 1

\begin{tabular}{|c|c|c|c|c|c|c|}
\hline Model & & $\begin{array}{l}\text { Sum of } \\
\text { Squares }\end{array}$ & Df & Mean Square & $\mathrm{F}$ & Sig. \\
\hline \multirow[t]{3}{*}{1} & Regression & 13885.137 & 1 & 13885.137 & 192.302 & $.000^{\mathrm{b}}$ \\
\hline & Residual & 10902.915 & 151 & 72.205 & & \\
\hline & Total & 24788.052 & 152 & & & \\
\hline
\end{tabular}

a. Dependent Variable: KPM

b. Predictors: (Constant), AQ

Berdasarkan tabel uji ANOVA Hipotesis 1 diketahui bahwa nilai sig $=0,000 \geq 0,05$. Sehingga dapat dismpulkan bahwa model regresi untuk hipotesis yang ditemukan dapat digunakan untuk memprediksi variable $\mathrm{Y}$.

Table 8 Output Coefficient Hipotesis 1

\begin{tabular}{llrrrrr}
\hline & \multicolumn{5}{c}{ Unstandardized } & \multicolumn{2}{c}{ Standardized } \\
Coefficients & \multicolumn{2}{c}{ Coefficients } & \\
Model & & B & Std. Error & Beta & \multicolumn{1}{c}{ t } & Sig. \\
\hline 1 & (Constant) & -8.488 & 5.469 & & -1.552 & .123 \\
& AQ & .856 & .062 & .748 & 13.867 & .000 \\
\hline
\end{tabular}

a. Dependent Variable: KPM

Tabel di atas memperlihatkan bahwa nilai signifikansi pada baris AQ (Adversity Quotient) adalah 0,000 yang lebih dari 0,05. Dengan demikian dapat disimpulkan bahwa Terdapat Pengaruh Adversity Quotient Terhadap Kemampuan Pemecahan Masalah Matematis Siswa SD Se Kecamatan Malili. Berdasarkan tabel di atas dapat pula ditemukan persamaan regresi adalah sebagai berikut ini.

$$
Y=-8,488+0,856 X_{1}
$$

Persamaan di atas menunjukkan bahwa jika tidak ada peningkatan Adversity Quotient maka kemampuan pemecahan masalah konsisten pada nilai $-8,488$. Selain itu, setiap penambahan 1 pada Adversity Quotient maka terjadi peningkatan kemampuan pemecahan masalah sebesar 0,856 .

2. Pemabahasan

Data di atas memperlihatkan bahwa jumlah siswa dengan Adversity Quotient kategori quitter sebanyak 13 siswa, kategori camper sebanyak 122 siswa, dan kategori climber sebanyak 18 siswa. Sehingga dapat disimpulkan bahwa sebagian besar siswa berada pada tingkat Adversity Quotient kategori Sedang. Artinya adalah siswa di kecamatan Malili memiliki tingkat Control, Origin dan Ownership, Reach, Endurance (daya tahan) pada kategori sedang juga. Dengan demikian secara teori siswa di Kecamatan memiliki level Adversity Quotient kategori Camper.

Siswa di Kecamatan cenderung memiliki control terhadap diri yang baik. Hal ini diperlihatkan dari respon siswa terhadap matematika yang tidak membuat mereka putus asa meskipun Sebagian dari mereka merasa bahwa matematika itu pelajaran yang sulit. Kontrol diri 
yang baik juga diperlihatkan dengan tepat waktu masuk belajar matematika, mengerjakan soal matematika dengan serius, dan tidak mengantuk ketika belajar matematika.mereka juga selalu berharap mendapatkan nilai matematika yang bagus sehingga selalu berusaha mengerjakan soal dengan maksimal. Hal tersebut sejalan dengan pendapat (Huijuan, 2009) bahwa AQ merupakan salahsatu faktor yang dapat mempengaruhi prestasi akademik siswa.

Siswa kategori climber di Kecamatan Malili tentunya akan lebih cepat membuat keputusan untuk menelukan cara yang tepat untuk mengerjakan soal pemacahan masalah matematis karena mereka hanya membutuhkan waktu yang singkat untuk memahami soal matematika. Mereka lebih keras berusaha untuk memahami cara mengerjakan soal dengan cara terus belajar matematika sampai mendapatkan prestasi yang maksimal. Selain itu meraka mampu menjelaskan jawaban yang telah diperoleh dan berani mejelaskannya di depan kelas. Widyastuti, (2015) menjelaskan bahwa siswa dengan tipe climber ini tidak pernah mengeluh terhadap masalah yang diberikan. Siswa tidak begitu saja meyakini kebenaran dari hasil yang telah diperolehnya sebelum siswa melakukan pemeriksaan kembali terhadap hasilnya tersebut.

Ditinjau dari Indikator Control sebagian besar siswa SD di Kecamatan Malili memberikan respon mendekati angka 3 atau jika dikategorikan positif. Hal tersebut berarti bahwa siswa SD di Kecamatan Malili merasa bahwa matematika tidak membuat mereka putus asa dan menggap matematika itu tidak terlalu sulit. Persepsi siswa yang paling dominan terlihat berdasarkan indicator control adalah siswa di Kecamatan selalu tepat waktu masuk belajar matematika, mereka mengerjakan soal matematika dengan serius dan maksimal.

Ditanjau dari Indikator Origin dan Ownership sebagian besar siswa SD di Kecamatan Malili juga memberikan respon positif. Berdasarkan penelitian ini, siswa pada kategori ini akan lebih cenderung memilih matematika dari pada pelajaran lain, mereka akan berusaha lebih keras untuk memahami cara mengerjakan soal matematika, mereka akan terus belajar matematika sampai mendapatkan prestasi yang maksimal, mereka juga akan mampu menjelaskan jawaban yang telah mereka peroleh.

Ditinjau dari segi jangkauan (reach) siswa di Kecamatan malili memiliki tingkat jangkauan yang sedang. Artinya adalah mereka baru merasakan kepuasan ketika telah menemukan jawaban pada soal matematika. Sehingga jika menemukan soal yang sulit mereka tetap maju dan berusaha semaksimal mungkin mengerjakan soal sampai menemukan jawabannya. Jika siswa memiliki AQ yang tinggi dalam belajar terutama dalam pelajaran matematika, maka siswa akan tetap melakukan usaha lebih karena siswa yang memiliki AQ tinggi akan memiliki motivasi belajar yang tinggi pula. Inilah yang akan mengantar siswa pada pencapaian prestasi atau hasil belajar yang lebih baik dan memuaskan (Rukmana, Hasbi, \& Paloloang, 2016).

Ditinjau dari indicator endurance (Daya Tahan) siswa juga memberikan respon positif. Penelitian ini menghasilkan bahwa siswa pada kategori ini akan mencoba menyelesaikan soal matematika sampai selesai. Mereka akan lebih berusaha untuk terus menyelesaikan soal matematika meskipun mereka belum mengetahui jawabannya. Permasalahan yang sedang terjadi hanya bersifat sementara dan akan segera selesai sehingga individu mampu untuk bertahan dalam waktu lama dalam menghadapi permasalahan tersebut (Hardianto, \& Sucihayati, 2019).

Hasil penelitian menunjukkan bahwa terdapat pengaruh Adversity Quotient dan Self Determination terhadap Kemampuan Pemecahan Masalah Matematis Siswa SD Di Kecamatan Malili baik secara Bersama sama maupun secara parsial. Secara parsial berdasarkan koefisien nilai X bertanda positif sehingga dapat ditarik suatu kesimpulan bahwa Adversity Quotient Siswa berpengaruh positif terhadap Kemampuan Pemecahan Masalah Matematis SD Di Kecamatan Malili. Artinya adalah semakin tinggi Adversity Quotient siswa maka semakin tinggi pula Kemampuan Pemecahan Masalah yang dimiliki siswa tersebut. Sejalan dengan (Afri, 2018) bahwa semakin tinggi AQ, semakin besar kemungkinan seseorang untuk bersikap 
optimis dan inovatif dalam mengatasi kesulitan serta bertanggung jawab untuk menyelesaikan masalah. Hal tersebut karena Adversity Quotient merupakan kemampuan yang dimiliki seseorang untuk mengubah dan mengolah suatu permasalahan atau kesulitan yang terjadi dalam hidupnya dan menjadikan masalah tersebut menjadi suatu tantangan yang harus diselesaikan dengan sebaik-baiknya (Widyastuti, R. 2015).

\section{Kesimpulan}

1. Rata - rata Tingkat Adversity Quotient Siswa SD di Kecamatan Malili adalah 87.92 dengan Standar Deviasi 11.17 atau berada pada kategori sedang atau camper.

2. Rata - Rata Kemampuan Pemecahan Masalah Matematis Siswa SD di Kecamatan Malili adalah 66,76 dengan standar deviasi 2,77 atau berada pada kategori sedang.

3. Terdapat pengaruh Adversity Quotient terhadap Kemampuan Pemecahan Masalah Matematis Siswa SD se Kecamatan Malili. Berdasarkan nilai koefisien $X_{1}$ ditetapkan bahwa Adversity Quotient berpengaruh positif terhadap Kemampuan Pemecahan Masalah Matematis Siswa SD se Kecamatan Malili dengan nilai Sig $=0,000 \leq \alpha=$ 0,05 .

\section{DAFTAR PUSTAKA}

Afri, L. D. (2018). Hubungan adversity quotient dengan kemampuan pemecahan masalah siswa SMP pada pembelajaran matematika. AXIOM: Jurnal Pendidikan Dan Matematika, 7(2).

Dewi, M., \& Suhendri, H. (2017). Pengaruh Kemandirian Dan Ketahanmalangan (Adversity Quotient) Terhadap Kemampuan Pemecahan Masalah Matematika. Makalah disajikan pada Diskusi Panel Nasional Pendidikan Matematika, Fakultas Teknik, Matematika, dan Ilmu Pengetahuan Alam, Jakarta 2017

Hardianto, Y., \& Sucihayati, R. B. (2019). Hubungan adversity quotient dengan career adaptability pada koas angkatan 2015 Fkg "X” di Rsgm. Psibernetika, 11(2).

Hidayat, W., \& Sariningsih, R. (2018). Kemampuan Pemecahan Masalah Matematis Dan Adversity Quotient Siswa SMP Melalui Pembelajaran Open Ended. JNPM (Jurnal Nasional Pendidikan Matematika), 2(1), 109-118.

Hikmatussyarifah, H., Hasanah, U., \& Tarma, T. (2016). Pengaruh Kelekatan Keluarga Terhadap Adversity Quotient Pada Mahasiswa Bidik Misi. Jurnal Kesejahteraan Keluarga dan Pendidikan, 3(2), 94-99.

Huijuan, Z. (2009). The Adversity Quotient and Academic Performance Among College Students at St. Joseph's College, Quezon City. Tesis. [online]. Tersedia di: www. peaklearning.com

Rosita, D., \& Rochmad, R. (2016). Analisis Kesalahan Siswa Dalam Pemecahan Masalah Ditinjau Dari Adversity Quotient Pada Pembelajaran Creative Problem Solving. Unnes Journal of Mathematics Education Research, 5(2), 106-113. 
Rukmana, I., Hasbi, M., \& Paloloang, B. (2016). Hubungan adversity quotient dengan hasil belajar matematika siswa kelas XI SMA Negeri Model Terpadu Madani Palu. Jurnal Elektronik Pendidikan Matematika Tadulako, 3(3), 325-333.

Stoltz, P.G. (2000). Adversity Quotient: Mengubah Hambatan Menjadi Peluang. Terjemahan: T. Hermaya. Jakarta: Gramedia Widiasarana Indonesia

Sudarman. (2012). Adversity Quotient Pembangkit Motivasi Siswa dalam Belajar Matematika. Kreatif. 15(1), 26-40.

Widjajanti, D. B. (2009). Kemampuan Pemecahan Masalah Matematis Mahasiswa Calon Guru Matematika: Apa Dan Bagaimana Mengembangkannya. Makalah disajikan pada Seminar Nasional Matematika dan Pendidikan Matematika, Universitas Negeri Yogyakarta, Yogyakarta. 5 Desember 2009.

Widyastuti, R. (2015). Proses berpikir siswa dalam menyelesaikan masalah matematika berdasarkan teori Polya ditinjau dari adversity quotient tipe climber. Al-Jabar: Jurnal Pendidikan Matematika, 6(2), 183-194. 